\title{
Intra-Abdominal Lymph Node
}

National Cancer Institute

\section{Source}

National Cancer Institute. Intra-Abdominal Lymph Node. NCI Thesaurus. Code C12360.

Any lymph node within the abdomen. 